\title{
Benzathine penicillin $G$ for the management of early syphilis among HIV co-infected persons: A systematic review
}

\author{
Niragira $\mathrm{O}^{1}, \mathrm{Ha} \mathrm{S}^{1}$, Pogany $\mathrm{L}^{1 *}$, Singh $\mathrm{A}^{2}$
}

\begin{abstract}
Background: The optimal treatment for syphilis in people who are human immunodeficiency virus (HIV) positive is controversial.

Objective: To assess the efficacy of three doses versus a single dose of long acting Benzathine Penicillin G (BP-G) for the effective management of early syphilis among HIV co-infected populations.

Methods: A systematic search of the published literature was conducted using MEDLINE and EMBASE databases to identify clinical and observational studies published between January 2010 and May 2015. Inclusion criteria were: publication in English or French, populations coinfected with HIV and early syphilis, treatment with BP-G and outcomes related to syphilis treatment. All articles underwent a risk of bias assessment and data extraction was completed on all included studies.
\end{abstract}

Results: Seven studies were eligible for final inclusion, data extraction and analysis. The evidence from the final included studies were from non-randomized controlled trials. In general, no significant differences were found between groups treated with one versus two or more doses of BP-G; but there was a trend toward longer time to treatment failure with three doses. Differences in methodology limit the ability to draw any firm conclusions on the relative efficacy between these two treatment regimens.

Conclusion: Insufficient data exist to ascertain whether or not there is an added benefit from additional doses of BP-G for the treatment of early syphilis with HIV co-infection. A high-quality, randomized controlled trial is needed to definitively nswer this question.

\author{
Affiliations \\ ${ }^{1}$ Centre for Communicable \\ Diseases and Infection Control, \\ Infectious Disease Prevention and \\ Control Branch, Public Health \\ Agency of Canada, Ottawa, ON \\ 2University of Alberta, Department \\ of Medicine, Edmonton, AB \\ *Correspondence: \\ lisa.pogany@phac-aspc.gc.ca
}

Suggested citation: Niragira O, Ha S, Pogany L, Singh A. Benzathine penicillin G for the management of early syphilis among HIV co-infected persons: A systematic review. Can Comm Dis Rep 2016;42-2:30-36.

https://doi.org/10.14745/ccdr.v42i02a02

\section{Introduction}

The effective management of early syphilis (primary, secondary and early latent stages) among human immunodeficiency virus (HIV) co-infected persons is an important public health issue due to the resurgence of syphilis in Canada and globally (15). Between 2000 and 2012, the rate of infectious syphilis in Canada increased from 1.84 to 8.85 cases per 100,000 persons (4). Similar increases were also noted in Europe and the United States $(1,5)$.

The prevalence of early syphilis is higher among HIV co-infected persons than in the general population (6-8). In addition, case reports and case series suggest that co-infection with HIV can result in atypical or more severe manifestations of syphilis. HIV-positive persons are more likely to present with multiple, larger ulcers, primary and secondary infections can overlap and cerebrospinal fluid (CSF) abnormalities, ocular and ophthalmologic manifestations are more common (9-13). Intercurrent syphilis may also temporarily increase HIV viral load and reduce CD4 lymphocyte count $(14,15)$.

Furthermore, the optimal treatment for HIV-positive individuals co-infected with early syphilis has been controversial since early reports of treatment failures in the late 1980s which followed standard recommended treatment regimens (16). Since that time, a number of studies have been completed, but their small sample sizes, largely observational nature and methodological heterogeneity, has prevented the development of strong evidenced-based recommendations about optimal treatment in this situation. Current guidelines have been criticized for not guiding physicians (17) and ambiguity in recommendations has 
resulted in varied clinical practice (18). As a result, the optimal antibiotic regimen among individuals with early syphilis remains controversial and, at times, the guidance is unclear $(19,20)$.

Findings from a systematic review published in 2011 suggest that inadequate high-quality evidence exists to fully understand the efficacy of additional doses of BP-G for the management of early syphilis in individuals with HIV as measured by serologic response to treatment $(19,20)$. Further, it is unclear whether improved outcomes would be achieved from additional doses of BP-G and whether this would outweigh the requirement of individuals to adhere to additional painful injections scheduled over multiple clinical visits (19).

In order to address these issues, a systematic review of recent evidence was carried out to compare the efficacy of one versus three doses of BP-G in the treatment of adults with HIV and early syphilis infection.

\section{Methods}

\section{Search strategy}

A search of the published literature was conducted using the following electronic databases: MEDLINE, EMBASE, Cochrane Library, Clinical trials.gov, Canadian Agency for Drugs Technologies in Health and Scopus. Hand searches were also completed to identify any relevant studies that may have been missed in the initial search. Key words used for the search were: "syphilis" or "Treponema pallidum", "human immunodeficiency virus" or "HIV" and "follow-up" or "treatment".

\section{Eligibility criteria}

Eligibility criteria were designed to update a previous systematic review published in 2011 (19). Studies were eligible for inclusion if they were published between January 2010 and May 2015 in English or French. Studies were required to report upon early syphilis in adult populations who are HIV-positive and interventions comparing doses of BP-G. All eligible articles were required to report outcomes related to the biologic cure of early syphilis.

\section{Study selection}

A two-step process was used to exclude I ess relevant publications. Two authors (ON, SH) independently screened titles followed by abstracts. Any discrepancies were resolved in discussion with a third author (LP). Publications were excluded if they did not have the following key words: "HIV" or "human immunodeficiency virus" and "early syphilis" and "treatment" or "antibiotic" or "management" or "follow-up" or "therapy".

An a priori decision was made to use the ACROBAT-NRSI to assess risk of bias in included observational studies (21), the Cochrane risk of bias assessment tool for randomized controlled studies (RCT) (22) and for the accessing methodological quality of systematic reviews (AMSTAR) (23). Overall quality appraisal of each study was performed by two reviewers (ON, SH) and a third author (LP) was consulted to resolve any disagreement.

\section{Data extraction}

Two authors (ON, SH) extracted information on the study design, target population, sample size and intervention. The lack of consistency of reported data did not allow for metaanalysis. Therefore, results were summarized in a narrative format.

\section{Results}

A total number of 328 citations were identified through different databases and hand searches (Appendix 1). After the title screening, 21 citations were retained for abstracts screening. Finally, seven publications were excluded based on language $(24)$, study design $(25,26)$ or absence of treatment data (27-30). The remaining 14 studies were eligible for full text retrieval. Seven studies were excluded for the following reasons: not early syphilis (31-33) or unspecified treatment information (34-36). Seven final publications were included for data extraction and synthesis. Key characteristics of the included studies are reported in Table 1 (excludes two systematic reviews).

\section{Study Characteristics}

Among the included publications, there were two systematic reviews and five studies of observational design (two prospective cohort studies and three retrospective studies). The systematic review by Blank et al. was focused on HIV coinfected population (19); however, the review by Clement et al., focused more broadly on syphilis with some discussion of HIV co-infection (20). Studies were conducted in Taiwan (37), the United States (38) and Europe (39-41). The participants in the studies were predominantly male. In four studies, the intervention was one or three doses of BP-G $(37,39-41)$. A single study compared one dose of BP-G with two or more doses of BP-G (38) (Table 1).

\section{Risk of bias of included studies}

There were no high-quality intervention studies available to include in the update and therefore the overall body of evidence includes important biases (Table 1). The possibility of the introduction of selection biases through lack of randomization is important. Of additional concern, the publications generally did not adjust for the known confounder of HIV treatment status or other comparable measures (e.g., CD4 count). In addition, the publications often did not stratify participants by stage of syphilis and HIV status (including treatment) and there were often considerable missing data (Table 2). 
Table 1. Characteristics of included studies

\begin{tabular}{|c|c|c|c|c|c|c|}
\hline Author & Number $^{1}$ & $\begin{array}{l}\text { Country } \\
\text { of study }\end{array}$ & $\begin{array}{c}\text { HIV } \\
\text { treatment }\end{array}$ & $\begin{array}{c}\text { Pharmacological } \\
\text { regimen }\end{array}$ & $\begin{array}{l}\text { Follow-up } \\
\text { period }\end{array}$ & Outcome measure \\
\hline Cousins (39) 2012 & $\begin{array}{l}62 \text { (3 dose) } \\
\text { Unclear } \\
\text { (1 dose) }\end{array}$ & $\begin{array}{l}\text { United } \\
\text { Kingdom }\end{array}$ & $\begin{array}{l}\text { Unspecified: } \\
\text { Some patients } \\
\text { receiving } \\
\text { antiretroviral } \\
\text { therapy (ART) }\end{array}$ & $\begin{array}{l}1 \text { dose: BP-G 2.54 MU } \\
\text { versus } 3 \text { doses: BP-G } \\
2.4 \mathrm{MU}\end{array}$ & 12 months & $\begin{array}{l}\text { Serological cure (4- } \\
\text { fold decrease in serum } \\
\text { RPR or serofast for } 12 \\
\text { months) }\end{array}$ \\
\hline Knaute (40) 2012 & 88 & Switzerland & Not specified & $\begin{array}{l}1 \text { dose: BP-G 2.4 MU } \\
\text { versus } 3 \text { doses: BP-G } \\
2.4 \mathrm{MU}\end{array}$ & $\begin{array}{l}3,6,8,9,12,18,24 \\
\text { months }\end{array}$ & $\begin{array}{l}\text { Serological Response } \\
\text { (VDRL, TPPA, } \\
\text { Pathozyme IgM) }\end{array}$ \\
\hline Tittes (41) 2013 & 84 & Austria & $\begin{array}{l}44 \%(35 / 80) \\
\text { were on ART }\end{array}$ & $\begin{array}{l}1 \text { dose: BP-G } 2.4 \mathrm{MU} \\
\text { versus } 3 \text { doses: BP-G } \\
2.4 \mathrm{MU}\end{array}$ & 3,6 and 12 months & $\begin{array}{l}\text { Serological cure } \\
\text { (4-fold decrease in } \\
\text { VDRL within } 6 \text { months) } \\
\text { Time to cure (days) }\end{array}$ \\
\hline Yang (45) 2014 & 420 & Taiwan & $\begin{array}{l}63.2 \%(362) \text { on } \\
\text { combination } \\
\text { ART }\end{array}$ & $\begin{array}{l}1 \text { dose: BP-G 2.4 MU } \\
\text { versus } 3 \text { doses: BP-G } \\
2.4 \mathrm{MU}\end{array}$ & 6 and 12 months & $\begin{array}{l}\text { Serological response } \\
\text { (4-fold decrease or } \\
\text { greater in RPR titres at } \\
12 \text { month follow-up) }\end{array}$ \\
\hline Ganesan (38) 2015 & $\begin{array}{l}286(393 \\
\left.\text { infections }^{2}\right)\end{array}$ & $\begin{array}{l}\text { United } \\
\text { States }\end{array}$ & $\begin{array}{l}59 \% \text { used } \\
\text { Highly active } \\
\text { retroviral } \\
\text { therapy }(\mathrm{H}) \text { at } \\
\text { first syphilis } \\
\text { case }\end{array}$ & $\begin{array}{l}1 \text { dose: } \mathrm{BP}-\mathrm{G} 2.4 \mathrm{MU} \\
\text { versus } \geq 2 \text { doses: } \mathrm{BP}-\mathrm{G} \\
2.4 \mathrm{MU}\end{array}$ & $\begin{array}{l}3,6,9,12,18,24 \\
\text { months }\end{array}$ & $\begin{array}{l}\text { Serologic response } \\
\text { Seroconversion }\end{array}$ \\
\hline
\end{tabular}

Abbreviations: BP-G, benzathine penicillin G; HIV, human immunodeficiency virus; IgM, immunoglobulin M; MU, million units; RPR, rapid plasma regain test; VDRL, Venereal Disease Research Laboratory test; TPPA, Treponema pallidum particle agglutination assay.

1 Number of study participants analyzed and not necessarily the total number of infections

2 Reflects the number of cases as some study subjects contributed more than one infection

\section{Outcomes}

Overall, four observational studies not included in the 2011 and 2014 systematic reviews included sample sizes of 62 to 350 subjects and concluded that there were no differences in serologic response at 12 ( $n=2$ or 3 studies) or 24 months ( $n=1$ study) if one or three doses BP-G were given (38-41). The fifth and largest, observational study conducted to date $(n=573)$ in Taiwan hypothesized that one dose was not inferior to three weekly doses of BP-G and set the significant difference between regimens as $10 \%$ of participants with a serologic response at 12 months. Yang et al. were unable to demonstrate that one dose was not inferior to three doses of BP-G (37).

\section{Serologic response}

Serologic response to syphilis treatment is monitored by serial testing using the rapid plasma reagin (RPR). The RPR is a nonspecific test that detects both $\lg M$ and $\lg G$ antibodies and is a measure of response to treatment (42). In the included studies, serologic response was commonly defined as $\geq 4$ fold reduction in RPR titres at 12 months.

Among the included publications, four did not show a benefit from additional doses beyond the standard therapy of 2.4 million units in a single dose of BP-G $(37,39-41,43)$. Yang et al.'s study was suggestive of a positive effect from additional doses: The effect was statistically significant when analyzed by last known results $(p=0.04)$ but not when analyzed per protocol $(p=0.24)(37)$.

The time to the first episode of serological failure appeared shorter in the group that received one dose: 1,184 (40 months) days for one-dose group and 1,436 days (almost 48 months) in the three-dose group, suggesting benefit from a three-dose regimen (37). In the same study, a Kaplan-Meier survival plot model showed a statistically significant longer mean time to failure in the group that received three-dose regimen $(p=0.03)$ (37).

\section{HIV status}

Co-infection with HIV impacts the manifestations and potential response to treatment of early syphilis. Therefore, the use of anti-retroviral therapy is an important characteristic to include when assessing the efficacy of syphilis therapy. Tittes et al. found a slower response to one-dose therapy within an HIV-positive group compared to an HIV-negative group, but there was no significant benefit when the two groups were treated with the three-dose regimen (41). Ganesan et al. found similar findings when comparing populations with CD4 $<500$ cells $/ \mu \mathrm{L}$ compared to CD4 $\geq 500$ cells $/ \mu \mathrm{L}(p=0.012)$ and the Knaute et al. publication reported a statistically 
Table 2: Summarized results for single and multiple doses of benzathine penicillin G for early syphilis in HIV co-infected persons from observational studies.

\begin{tabular}{|c|c|c|c|c|c|}
\hline \multirow[t]{2}{*}{ Author } & \multirow{2}{*}{$\begin{array}{l}\text { BP-G } \\
\text { doses }^{1}\end{array}$} & \multicolumn{2}{|c|}{$\begin{array}{c}\text { Serological response }{ }^{2} \text { at } 12 \\
\text { months }\end{array}$} & \multicolumn{2}{|c|}{ HIV association with serological response } \\
\hline & & Response & $p$ value & Response & $p$ value \\
\hline \multirow{2}{*}{$\begin{array}{l}\text { Cousins (39) } \\
2012\end{array}$} & 1 dose & $78.9 \%(95 \% \mathrm{Cl} 68.0-89.8)$ & $p>0.05$ & N/A & \\
\hline & 3 doses & $64.1 \%(95 \% \mathrm{Cl} 45.0-73.2)$ & & N/A & \\
\hline \multirow{2}{*}{$\begin{array}{l}\text { Knaute (40) } \\
2012\end{array}$} & 1 dose & $100 \%$ & & HIV-negative (reference) & \\
\hline & 3 doses & $100 \%$ & & $\begin{array}{l}\mathrm{CD} 4 \geq 500 \mathrm{HR} 1.27(95 \% \mathrm{Cl} 0.79-2.04) \\
\mathrm{CD} 4<500 \mathrm{HR} 0.83(95 \% \mathrm{Cl} 0.60-1.14)\end{array}$ & $\begin{array}{l}p=0.332 \\
p=0.241\end{array}$ \\
\hline \multirow{2}{*}{$\begin{array}{l}\text { Tittes (41) } \\
2013\end{array}$} & 1 dose & $88 \%$ & & \multirow{2}{*}{$\begin{array}{l}\text { No correlation between viral suppression and outcome- } \\
\text { data not shown }\end{array}$} & $p=0.18$ \\
\hline & 3 doses & $97 \%$ & & & \\
\hline \multirow{2}{*}{$\begin{array}{l}\text { Yang (45) } \\
2014\end{array}$} & 1 dose & $66.2 \%(95 \% \mathrm{Cl} 59.6-72.4)$ & $p=0.24$ & CD4 $\leq 200$ (reference) & \\
\hline & 3 doses & $71.8 \%(95 \% \mathrm{Cl} 64.7-78.2)$ & & $\begin{array}{l}200<\mathrm{CD} 4 \leq 350 \mathrm{OR}_{\mathrm{ADJ}} 1.05(95 \% \mathrm{Cl} 0.54-2.07) \\
\mathrm{CD} 4>350 \mathrm{OR}_{\mathrm{ADJ}} 1.51(95 \% \mathrm{Cl} 0.69-3.51)\end{array}$ & $\begin{array}{l}p=0.88 \\
p=0.30\end{array}$ \\
\hline \multirow{2}{*}{$\begin{array}{l}\text { Ganesan } \\
\text { (38) } 2015\end{array}$} & 1 dose & $92 \%$ & & \multirow[t]{2}{*}{ CD4 (per 100-cell increase) HR 1.07 (95\% Cl 1.01-1.12) } & $p=0.02$ \\
\hline & $\geq 2$ doses & $92 \%$ & & & \\
\hline
\end{tabular}

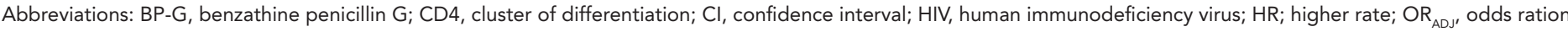
adjusted.

1 Dose $=2.4$ million units BP-G IM in a single dose

2 Proportion of subjects who exhibited response to therapy defined as a $\geq 4$-fold decline in nontreponemal titre

significant association between higher CD4 count and time to response to therapy $(38,40)$.

\section{Harms}

The included publications did not document harms of therapy. Up to $10 \%$ of the population will report allergies to penicillin (44), potentially posing challenges to the use of BP-G. In addition, the intramuscular route of administration is painful and the additional health care visits are a potential burden to both the health care system as well as the patient.

\section{Discussion}

This review confirms that there is limited evidence to definitively guide management decisions in HIV-infected persons with early syphilis infection. The foundational 2011 systematic review concluded that the optimal treatment regimens remain unknown (19) and, although limited in its focus on HIV-positive individuals, the 2014 systematic review (20) concluded that in the absence of compelling data, individuals with HIV infections should be treated similarly to uninfected patients. This review of additional studies not included in these systematic reviews is consistent with the recommendation to use single-dose BP-G for HIV coinfected patients based on serologic response as the treatment outcome.

Of note, however, was the finding by Yang et al., which suggested a possible benefit of three doses of BP-G by reporting a longer time to serologic treatment failure in this group (37).
However, the authors described a number of limitations to the study that could potentially explain the difference in their findings relative to other studies: 1) the study was not a RCT; 2) the decision to use one vs three doses was made by physicians assessing the patients; 3 ) $25 \%$ had missing RPR titres on followup testing; 4 ) the researchers could not definitely differentiate between re-infection and treatment failure; and, 5) the majority of patients were men who have sex with men (MSM) which limited the generalizability of their findings to other populations. In later correspondence, the same authors reported that the proportion of HIV co-infected patients with early syphilis treated with three doses at the eight centres in Taiwan declined from $60.2 \%$ in $2007-2009$ to $25 \%$ in 2012 after a change in the Centre for Disease Control and Prevention (CDC) guidelines recommending single-dose BP-G (45).

Finally, results suggested that individuals with the highest CD4 counts had lower risk of poor serologic response to treatment $(40,45)$.

\section{Strengths and limitations}

Strength of this review is that it is built on a previous systematic review and that it took all precautions to minimize bias. However, a number of limitations need to be considered when interpreting the results. Included studies were limited by their design and the potential impact of selection bias through the lack of randomization to dosing schedules contributes important potential biases to the results. The lack of adjustment for HIV treatment /status (anti-retroviral therapy and CD4 count) further limits the ability to extrapolate results to the 
clinical setting. These are known and significant associations (37) but the included publications were not analyzed with a stratified or multivariate approach (37,39-41). Studies were not representative of the entire population at risk for syphilis and HIV co-infection. More than $80 \%$ (and as high as $99 \%$ ) of included study participants were male, of which the majority appeared to be MSM. Ideally, an adequately-powered RCT with clearly stratified HIV populations including women and with sufficiently long follow-up periods should be conducted to more definitely answer this question.

\section{Conclusion}

Our review found that the recent publications do not demonstrate a clear benefit to additional doses of BP-G for the treatment of individuals with early syphilis and HIV co-infection; more definitive trails are needed.

\section{Appendix 1: Inclusion and exclusion of publications}

\section{Acknowledgements}

The authors would like to acknowledge Ella Westhaver for her support with systematic searches through electronic databases and the technical contribution of the Expert Working Group for the Canadian Guidelines for Sexually Transmitted Infections.

\section{Conflict of interest}

None to declare.

\section{Funding}

This systematic review was funded by the Public Health Agency of Canada.

\section{References}

1. Fenton KA, Imrie J. Increasing rates of sexually transmitted diseases in homosexual men in Western Europe and the United States: Why? Infect Dis Clin North Am. 2005 Jun;19(2):311-31.

2. Chen ZQ, Zhang GC, Gong XD, Lin C. Syphilis in China: Results of a national surveillance programme. Lancet. 2007;369(9556):132-138.

3. Mayor S. Syphilis and gonorrhoea increase sharply in England. BMJ. 2015;350(h3457).

4. Public Health Agency of Canada. Notifiable diseases online (1993 to 2012). Ottawa, ON: PHAC; 2016. http://dsol-smed. phac-aspc.gc.ca/dsol-smed/ndis/charts.php?c=yl.

5. Patton ME, Su JR, Nelson R, Weinstock H. Centers for Disease Control and Prevention (CDC). Primary and secondary syphilis-United States, 2005-2013. MMWR Morb Mortal Wkly Rep. 2014;63(18):402-406.

6. Giuliani M, Palamara G, Latini A, Maini A, Di Carlo A. Evidence of an outbreak of syphilis among men who have sex with men in Rome. Arch Dermatol. 2005;141(1):100-101.

7. Golden MR, Marra CM, Holmes KK. Update on syphilis: Resurgence of an old problem. JAMA. 2003;290(11):15101514.

8. Solomon MM, Mayer KH, Glidden DV, Liu AY, McMahan VM, Guanira JV, et al. Syphilis predicts HIV incidence among men and transgender women who have sex with men in a preexposure prophylaxis trial. Clin Infect Dis. 2014;59(7):10201026.

9. Rompalo A. Preventing sexually transmitted infections: Back to basics. J Clin Invest. 2011;121(12):4580-4583.

10. Orlova IA, Smirnova IO, Korobko AV, Petunova YG, Smirnova TS, Dudko VU, et al. Ophthalmic and otolaryngological manifestations of syphilis in patients with HIV. Sex Transm Infect. 2013 Jul;89(1):A1-A428. 
11. Perez-Martin I, Blanco R, Fonollosa A, Sorribas M, Diaz-Valle D, Adan A, et al. Syphilitic uveitis: A multicenter study of 50 cases. Ann Rheum Dis. 2013 Jun;71:2012-2015.

12. Zetola NM, Klausner JD. Syphilis and HIV infection: An update. Clin Infect Dis. 2007;44(9):1222-1228.

13. Marra CM, Maxwell CL, Smith SL, Lukehart SA, Rompalo AM, Eaton M. Cerebrospinal fluid abnormalities in patients with syphilis: Association with clinical and laboratory features J Infect Dis. 2004;189(3):369-376.

14. Buchacz K, Patel P, Taylor M, Herndt PR, Byers RH, Holmberg SD. Syphilis increases HIV viral load and decreases CD4 cell counts in HIV-infected patients with new syphilis infections. AIDS. 2004;18(15):2075-2079.

15. Read PJ, Fox J. Infectious syphilis unmasking drug resistance in an individual with long term virological suppression on anti-retroviral therapy. Sex Transm Infec. 2010;86(4):276-277.

16. Wright RG, Rotheram-Borus MJ, Klosinski L, Ramos B, et al. Screening for transmission behaviors among HIV-infected adults. AIDS Educ Prev. 2000 Oct;12(5):431-41.

17. Wu G, Zaman MH. Low-cost tools for diagnosing and monitoring HIV infection in low-resource settings. Bull World Health Organ, 2012 Dec;90(12):914-920.

18. Wright WW. Rapid HIV testing in labor and delivery settings. QRC Advis 2000;16(5):4-9.

19. Blank LJ, Rompalo AM, Erbelding EJ, Zenilman JM, Ghanem KG. Treatment of syphilis in HIV-infected subjects: A systematic review of the literature. Sex Transm Infect. 2011;87(1):9-16.

20. Clement ME, Okeke NL, Hicks CB. Treatment of syphilis: A systematic review. JAMA. 2014;312(18):1905-1917.

21. Sterne JAC, Higgins JPT, Reeves BC, on behalf of the development group for ACROBAT- NRSI. A Cochrane risk of bias assessment tool: for Non-randomized studies of interventions (ACROBATNRSI), Version 1.0.0, 2014. http:// www.riskofbias.info.

22. Higgins JP, Altman DG, Gøtzsche PC, Jüni $P$, Moher D, Oxman AD, et al. The Cochrane Collaboration's tool for assessing risk of bias in randomised trials. BMJ. 2011;18(343):d5928.

23. Shea BJ, Grimshaw JM, Wells GA, Boers M, Andersson N, Hamel C, et al. Development of AMSTAR: A measurement tool to assess the methodological quality of systematic reviews. BMC Med Res Methodol. 2007;(7):10.

24. Cachay E, Mar-Tang M, Mathews WC. Screening for potentially transmitting sexual risk behaviors, urethral sexually transmitted infection and sildenafil use among males entering care for HIV infection. AIDS Patient Care STDS. 2004 Jun;18(6):349-354.

25. Frippiat F, Moutschen M. Syphilis treatment in the human immunodeficiency virus-infected patient: Follow the guidelines. Clin Infect Dis. 2011 Oct;53(8):845.
26. Farhi D, Dupin N. Management of syphilis in the HIVinfected patient: Facts and controversies. Clin Dermatol. 2010;28(5):539-545.

27. Maek-a-nantawat W, Avihingsanon A, Phonphithak S, Laopraynak N, Chaiya O, Ruxrungtham K. Factors associated with syphilis acquisition among HIV-infected MSM on antiretroviral therapy. 2014;41.

28. Opara Morrison I, Ogbebor Vivian O, Fasasi Muyideen A, Akanmu Sulaimon A, Bamiro Babajide S, Ayolabi Christianah I, et al. Incidences of hepatitis B and syphilis co-infection with HIV in antiretroviral treatment-naïve adult patients attending APIN clinic at a University Teaching Hospital in Lagos, Nigeria. J AIDS Clin Res. 2013;4(1).

29. Zoufaly A, Onyoh EF, Tih PM, Awasom CN, Feldt T. High prevalence of hepatitis $B$ and syphilis co-infections among HIV patients initiating antiretroviral therapy in the north-west region of Cameroon. Int J STD AIDS. 2012 Jun;23(6):435438.

30. Thurnheer MC, Weber R, Toutous-Trellu L, Cavassini M, Elzi $L$, Schmid $P$, et al. Occurrence, risk factors, diagnosis and treatment of syphilis in the prospective observational Swiss HIV Cohort Study. AIDS. 2010 Jul 31;24(12):1907-1916.

31. Dionne-Odom J, Karita E, Kilembe W, Henderson F, Vwalika $B$, Bayingana $R$, et al. Syphilis treatment response among HIV-discordant couples in Zambia and Rwanda. Clin Infect Dis. 2013 Jun;56(12):1829-1837.

32. Drayton $R$, Johnston CE. RPR titres following syphilis treatment: Does HIV status affect the magnitude or rate of response? Sex Transm Infect. 2012 June;88.

33. Amaratunge BC, Camuglia JE, Hall AJ. Syphilitic uveitis: A review of clinical manifestations and treatment outcomes of syphilitic uveitis in human immunodeficiency virus-positive and negative patients. Clin Exp Ophthalmol. 2010;38(1):6874.

34. Kim JH, Psevdos Jr. G, Suh J, Sharp V. Factors influencing syphilis treatment failure and/or re-infection in HIV coinfected patients: Immunosuppression or behaviors. Chin Med J. 2011;124(14):2123-2126.

35. Muldoon EG, Mooka B, Reidy D, O'Dea S, Clarke S, Courtney G, et al. Long-term neurological follow-up of HIVpositive patients diagnosed with syphilis. Int J STD AIDS. 2012 Sep;23(9):676-678.

36. Saje A, Tomazic J. Syphilis and HIV co-infection: Excellent response to multiple doses of Benzathine Penicillin. Acta dermatovenerolog Alp Pannon Adriat. 2014 Mar;23(1):1-3.

37. Yang C-, Lee $\mathrm{N}_{-}$, Chen $\mathrm{T}-$, Lin Y-, Liang S-, Lu P-, et al. One dose versus three weekly doses of benzathine penicillin $G$ for patients co-infected with HIV and early syphilis: A multicenter, prospective observational study. PLoS ONE. 2014;9(10).

38. Ganesan A, Mesner O, Okulicz JF, O'Bryan T, Deiss RG, Lalani $T$, et al. A single dose of benzathine penicillin $G$ is as effective as multiple doses of Benzathine Penicillin $G$ for the 
treatment of HIV-infected persons with early syphilis. Clin Infect Dis. 2015;60(4):653-660.

39. Cousins DE, Taylor M, Lee V. The outcome of treatment of early syphilis with different Benzathine Penicillin regimens in HIV-infected and -uninfected patients. Int J STD AIDS. 2012;23(9):632-634.

40. Knaute DF, Graf N, Lautenschlager S, Weber DR, Bosshard PP. Serological response to treatment of syphilis according to disease stage and HIV status. Clin Infect Dis. 2012 Dec;55(12):1615-1622.

41. Tittes J, Aichelburg MC, Antoniewicz L, Geusau A. Enhanced therapy for primary and secondary syphilis: A longitudinal retrospective analysis of cure rates and associated factors. Int J STD AIDS 2013;24(9):703-711.

42. Morshed MG, Singh AE. Recent trends in the serologic diagnosis of syphilis. Clin Vaccine Immunol 2015;22(2).

43. Wong AE, Garcia PM, Olszewski Y, Statton A, Bryant Borders A, Grobman WA, et al. Perinatal HIV testing and diagnosis in Illinois after implementation of the perinatal rapid testing initiative. Obstet Gynecol 2012;207(5):401.e1-401.e6.

44. Macy E., Ho N.J. Multiple drug intolerance syndrome: Prevalence, clinical characteristics and management. Ann Allergy Asthma Immunol. 2012;108(2):88-93.

45. Yang CJ, Chen YH, Tsai MS, Hung CC. Optimal dose of Benzathine Penicillin $\mathrm{G}$ for the treatment of early syphilis in HIV-infected patients in the era of combination antiretroviral therapy. Clin Infect Dis. 2015;60(9):1443-1444.Ganesan A, Mesner O, Okulicz JF, O’Bryan T, Deiss RG, Lalani T, et al. 